\title{
Topical Steroid Therapy
}

National Cancer Institute

\section{Source}

National Cancer Institute. Topical Steroid Therapy. NCI Thesaurus. Code C116545.

The application of steroid medications to the skin for the treatment of various conditions. 